\title{
Brexit and the International Law Prohibitions on the Loss of EU Citizenship
}

\author{
William Thomas Worster \\ The Hague University of Applied Sciences; Senior Lecturer, International \\ Law. PhD candidate in International Law, University of Amsterdam, Am- \\ sterdam, The Netherlands; llm (Adv) in Public International Law, cum laude, \\ Leiden University, Leiden, The Netherlands; jd, Chicago-Kent College of Law, \\ Illinois Institute of Technology, Chicago, Illinois. \\ wtworster@hotmail.com
}

\begin{abstract}
This submission challenges the presumption that U K nationals will lose EU citizenship following Brexit. Until now, the dominant narrative has been drawn from the law on treaties or international organizations, and this article adds the human rights perspective to Brexit. Firstly, EU citizenship can be assimilated to nationality. While EU citizenship is unique, the status protected under international law is a legal bond a person has with a political entity. This protection certainly covers nationality, and this paper argues it can be understood to also protect EU citizenship. Secondly, international law prohibits arbitrary withdrawal of this legal bond with a person. The UK does not have jurisdiction over EU citizenship, so it is doubtful the UK can terminate EU citizenship unilaterally. Even if the EU were to withdraw EU citizenship on its initiative, it would still constitute retroactive law, discrimination, and infringement of sovereignty. It is also disproportionate, because the loss of EU citizenship is not necessary for Brexit. When Greenland withdrew from the EU, its residents retained EU citizenship. For these reasons, the revocation of EU citizenship would be arbitrary. A distinction must be made between the membership of a state in the EU which can be terminated, and the direct legal bond formed between a person and the Union, which is far harder to revoke. On this basis, any UK national who has acquired EU citizenship prior to Brexit, should not be divested of it following Brexit.
\end{abstract}

(C) WILLIAM THOMAS WORSTER, 2018 | DOI 10.1163/15723747-01502005

This is an open access chapter distributed under the terms of the prevailing CC-BY-NC License at the time of publication. 


\section{Keywords}

Brexit - citizenship - nationality - deprivation - denationalisation - revocation proportionality

\section{Introduction}

This article examines the particular case of leaving an international organization when that organization is the unique case of the EU and the beneficiaries of the organization are EU citizens. The Treaty on European Union ('TEU') provides member states of the $\mathrm{EU}$ with the option to withdraw from membership under article $5{ }^{0 .}{ }^{1}$ Once the UK leaves the $\mathrm{EU}$, it cannot continue to enjoy the benefits of Union membership, eg, access to the common market, unless it receives those rights by separate agreement with the EU. This article, however, does not question whether the $\mathrm{UK}$, as a state, can continue to enjoy EU benefits, but rather whether UK nationals, as individuals with human rights pertaining to their citizenship, can continue to enjoy their EU citizenship.

The Treaty on the Functioning of European Union ('TFEU') creates a difficulty: European citizenship (art 20). While usually a state's membership in an international organization may produce benefits for its citizens, those citizens are not usually granted a direct right or status in the organization itself. That role is purely mediated by the state. However, in the case of the $\mathrm{EU}$, the nationals of the member states were placed into a direct legal relationship with the Union, from which they derive certain rights. This makes the situation far more complex than the usual paradigm of state membership in an international organization. It means that the narrative of Brexit cannot only look at the law of international organizations and perhaps the law of treaties to resolve questions of withdrawal, but must also, I argue, consider questions of the rights of human beings. If protecting their rights demands a different outcome, then the rights and relationships between and among the state, the organization and the individuals may fragment. This article will first examine the current international law pertaining to nationality and conclude that, while international law gives states a wide degree of discretion in granting nationality, it restricts their ability to revoke it. The key aspect of this conclusion is the protection of the legal bond with the state. Then the article will argue that E U citizenship, while not necessarily amounting to a nationality in the normal sense

1 See, for the EU Treaties, https://eur-lex.europa.eu/legal-content/EN/TXT/HTML/?uri=OJ:C:2 016:202:FULL\&from=EN. 
of that term, does amount to a functionally equivalent legal bond, sufficient to trigger the application of international law on nationality. Lastly, the article will test whether the proposed loss of EU citizenship in Brexit is in compliance with human rights law.

\section{International Human Rights Law on Nationality}

Before examining the international law on nationality, we first need to address the distinction between nationality and citizenship. Nationality generally refers to a legal bond with a state under international law. When the International Court of Justice was asked to determine nationality for purposes of diplomatic protection, the Court concluded that, for international law, nationality is a "legal bond having as its basis a social fact of attachment, a genuine connection of existence, interests and sentiments, together with the existence of reciprocal rights and duties". ${ }^{2}$ Similarly, the International Law Commission focused on "the link between the individual and international law"3 as the critical legal basis for nationality in international law. That bond is sometimes articulated as one of "allegiance", ${ }^{4}$ yet another problematic word. Another way to view nationality is to consider its reverse scenario, statelessness, or the absence of nationality. The 1954 Convention Relating to the Status of Stateless Persons defines a stateless person as "a person who is not considered as a national by any state under the operation of its law". ${ }^{5}$ Under this approach, a national is a person considered as such by a state under the operation of its law, primarily a legal status for purposes of the law.

Having discussed nationality, the next question is the nature of citizenship. Citizenship, for purposes of international law, is an aspect of nationality. The terms 'nationality' and 'citizenship' are almost always used interchangeably

2 See ibid 23; Albrecht Randelzhofer, 'Nationality' in 3 Encyclopedia of Public International Law 501, 502 (Oxford University Press 1997) ("Nationality as a legal term denotes the existence of a legal tie between an individual and a State, by which the individual is under the personal jurisdiction of that State").

3 See International Law Commission, Report of the International Law Commission Covering the Work of its Fifth Session, 1 June - 14 August 1953, UN Docs A/2456, A/CN.4/76 (1-14 August 1953) [130].

4 See C Tiburcio, The Human Rights of Aliens under International and Comparative Law (Martinus Nijhoff, 2011) 3 .

5 See Convention Relating to the Status of Stateless Persons, opened for signature 28 September 1954, 360 UNTS 117 (entered into force 6 June 1960). 
with the same meaning, ${ }^{6}$ and while there may be some legal difference, it is unclear whether that difference really has any significance under international law today. ${ }^{7}$ Generally nationality and citizenship refer to the same legal bond, though with an emphasis on the international and domestic legal positions, respectively. ${ }^{8}$ It may be that under a state's domestic law that citizenship has a particular meaning, and citizenship is often used to describe important social, cultural, local and linguistic ties. ${ }^{9}$ Some states do make distinctions between nationals and citizens. But we need to be careful here about which legal system we are discussing and how that system uses common words. Within a domestic legal system, there may be special meanings for 'national' and 'citizen', which could focus on rights or other considerations, but international law usage for the term 'national' is not completely dependent on domestic usage. For example, if a state granted nationality to a person, but refused citizenship, international law might still consider that person a national. It would not take a position on citizenship, because citizenship is the domestic reflection of nationality. However, under international law both of these statuses are acquired when an individual forms a legal bond with a state. ${ }^{10}$

Turning to the acquisition and loss of this legal bond, these two functions are not treated the same under human rights law. International law generally does not place restrictions on a state's discretion to grant nationality, ${ }^{11}$ though there are some exceptions. ${ }^{12}$ International law will, however, limit discretion in revoking nationality, and in this area the law is more restrictive than in

6 See Global Citizenship Observatory ('GLOBALCiT'), Citizenship <http://globalcit.eu/ glossary_citizenship_nationality/>: "Citizenship: A legal status and relation between an individual and a state that entails specific legal rights and duties. Citizenship is generally used as a synonym for nationality (see: nationality)".

7 See P Weis, Nationality and Statelessness in International Law (Sijthoff and Noordhoff, 2nd ed, 1979) 4-5: "Conceptually and linguistically, the terms 'nationality' and 'citizenship' emphasise two different aspects of the same notion: State membership. Nationality stresses the international, citizenship the national, municipal aspect".

8 See ibid.

9 See Linda Bosniak, 'Citizenship Denationalized' (2000) 7(2) Indiana Journal of Global Legal Studies $447,45^{2-489}$.

10 See Nottebohm Case (Liechtenstein v Guatemala) (Judgment, Second Phase) [1955] ICJ Rep 4, 8: "constitute[s] the juridical expression of the fact that the individual upon whom it is conferred ... is in fact more closely connected with the population of the State conferring nationality than with that of any other State".

11 See Exchange of Greek and Turkish Populations (Advisory Opinion) [1925] PCIJ (ser B) No 10, 19; R Jennings and A Watts (eds), Oppenheim's International Law (Oxford University Press, 9th ed, 1992) vol 1, 854-856.

12 See Nationality Decrees issued in Tunis and Morocco (French Zone) (Advisory Opinion) [1923] PCIJ (ser B) No 4, 24, 296; Proposed Amendments to the Naturalization Provisions 
acquisition of nationality. ${ }^{13}$ One limitation is the prevention of statelessness ${ }^{14}$ and the other way is the right of all persons to a nationality and thus the right against the arbitrary or discriminatory removal of nationality. ${ }^{15}$ Looking specifically at the prohibition on arbitrary revocation of nationality, this prohibition is both procedural and substantive. ${ }^{16}$ Procedurally, the revocation must have a legal basis ${ }^{17}$ and provide for a proper judicial process. ${ }^{18}$ Substantively,

of the Constitution of Costa Rica (Advisory Opinion) (Inter-American Court Human Rights, Case No oC-4/84, 19 January 1984) (reported at [1984] IACHR (ser A) No 4, 94).

13 See International Convention on the Elimination of Racial Discrimination, opened for signature 21 December 1965, 660 UNTS 195 (entered into force 4 January 1969) ('ICERD') art 5(d)(iii); European Convention on Nationality, opened for signature 6 November 1997, ETS 166 (entered into force 1 March 200o) ('Convention on Nationality') art 3(2); Ruth Donner, The Regulation of Nationality in International Law (Martinus Nijhoff, 2d ed 1994) 121-167; Weis, above n 7, 29; Manley Hudson, 'Nationality, Including Statelessness' [1952] II Yearbook of the International Law Commission 3, 10.

14 See Convention on the Reduction of Statelessness, opened for signature 30 August 1961, 989 UNTS 175 (entered into force 13 December 1975) ('Statelessness Convention'). Certainly this limitation applies to states party to the 1961 Statelessness Convention, but might also apply to states generally under customary international law. This author has argued elsewhere that such a rule applies under customary international law, but that argument will be omitted here because it is not necessary for the conclusions herein.

15 See, eg, Universal Declaration of Human Rights, UN Doc A/810 (10 December 1948) arts 13(2) and 15(2); International Covenant on Civil and Political Rights, opened for signature 16 December 1966999 UnTs 171 (entered into force 23 March 1976) arts 12(4); American Convention on Human Rights, opened for signature 22 November 1969, 1144 UNTS 123 (entered into force 18 July 1978); Convention on Nationality; African Charter on Human and Peoples' Rights, opened for signature 27 June 1981, 1520 unTs 363 (entered into force 21 October 1986) art 12(2); Eritrea v Ethiopia, Claims Commission, Partial Award: Civilian Claims: Eritrea's Claims 15, 16, 23 and 27-32 (Permanent Court of Arbitration, 17 December 2004); Human Rights Council Resolution 32/5, Human rights and arbitrary deprivation of nationality, un Doc A/HRC/32/L.8 (30 June 2016); Yean and Bosico Children v Dominican Republic (Judgment) (Inter-American Court Human Rights, 8 September 2005).

16 See Un Doc A/HRc/25/28 (19 December 2013) [40]; Human Rights Council, Arbitrary deprivation of nationality: report of the Secretary-General, UN Doc A/HRC/10/34 (26 January 2009) [49].

17 See Convention on Nationality, art 7; Explanatory Report to the European Convention on Nationality <https://rm.coe.int/CoERMPublicCommonSearchServices/DisplayDCTMC ontent?documentId=0900001680occde $7>$ [36], providing that denaturalisation must be foreseeable, proportional and provided in law; Ivcher Bronstein v Peru (Judgment) (InterAmerican Court Human Rights, 6 February 2001) [95].

18 See un Doc A/Hrc/13/34 (14 December 2009) [43]-[46], un Doc A/Hrc/25/28 (19 December 2013) [40] International Law Commission, 'Draft Articles on Nationality of Natural Persons in relation to the Succession of States, with commentaries' [1999] II(2) Yearbook 
the revocation must be reasonable,$^{19}$ in the sense that it has a legitimate aim, is proportionate, and is not inappropriate, unjust, illegitimate or unpredictable. ${ }^{20}$ The Court of Justice of the European Union ('CJEU') has recognised the restriction on arbitrary revocation of nationality as a "general principle of international law",21 although it is unclear whether the CJEU only views the procedural protection or also the substantive protection as a part of that principle. There are a variety of possible grounds for revocation of nationality that are considered arbitrary and/or discriminatory, such as race, gender, religion, etc. ${ }^{22}$ The European Convention on Nationality takes a different approach, identifying several examples of nationality revocation that are reasonable: voluntary acquisition of another nationality; acquisition of the nationality by fraud or deception; voluntary service in a foreign military force; conduct seriously prejudicial to the vital interests of the state; lack of a genuine link between the state and a national habitually residing abroad; or failure of a child to fulfill preconditions established by law. ${ }^{23}$ All other grounds are unreasonable. ${ }^{24}$

International Law Commission 38 art 17; Human Rights Committee, General Comment No 27: Article 12 (Freedom of Movement), UN Doc CCPR/C/21/Rev.1/Add.9 (2 November 1999).

19 See Case Concerning Elettronica Sicula S.p.A. (ELSI) (United States v Italy) (Judgment) [1989] ICJ Rep 65, [128] (citing Asylum Case (Colombia v Peru) (Judgment) [1950] ICJ Rep 284): "Arbitrariness is not so much something opposed to a rule of law, as something opposed to the rule of law"; Eritrea v Ethiopia, Claims Commission, Partial Award: Civilian Claims: Eritrea's Claims 15, 16, 23 and 27-32 (Permanent Court of Arbitration, 17 December 2004); Human Rights Committee, General Comment No 27: Article 12 (Freedom of Movement), Un Doc CCPR/C/21/Rev.1/Add.9 (2 November 1999) [21]. See also Stewart v Canada (Human Rights Committee, Communication No 538/1993) Un Doc CCPR/C/58/D/538/1993 (16 December 1996) Individual Opinion of Evatt and Medina Quiroga with Dissent of Aguilar Urbina [8].

20 See Van Alphen $v$ Netherlands, (Human Rights Committee, Communication No 305/1988) UN Doc CCPR/C/39/D/305/1988 (23 July 1990) [5](8); A v Australia, (Human Rights Committee, Communication No 56o/1993) Un Doc CCPR/C/59/D/56o/1993 (30 April 1997) [9] (2); Human Rights Committee, General Comment No 27: Article 12 (Freedom of Movement), UN Doc CCPR/C/21/Rev.1/Add.9 (2 November 1999).

21 See Rottman $v$ Freistaat Bayern (C-135/08) [2010] ECR I-01449, [53].

22 See Statelessness Convention, art 8; ICERD, art 5; UN Human Rights Council Resolution 20/5, Human rights and arbitrary deprivation of nationality, UN Doc A/HRC/RES/20/5 (16 July 2012); UN Human Rights Council Resolution 7/10, Human rights and arbitrary deprivation of nationality (27 March 2008); UNGA, Draft international declaration of human rights, UN Doc A/C.3/sR.123 $35^{2}$ (5 November 1948) (Eleanor Roosevelt: "individuals should not be subjected to action such as was taken during the Nazi regime in Germany when thousands had been stripped of their nationality by arbitrary government action"). See Convention on Nationality, arts 5(1) and 7(3).

24 See ibid. 


\section{EU Citizenship as a Legal Bond Sufficient to Trigger International Law}

EU 'citizenship' is highly unusual, ${ }^{25}$ with some scholars considering it as a new legal category of post-national citizenship, ${ }^{26}$ or a citizenship beyond the state. ${ }^{27}$ The only other citizenship of comparable form is ECOWAs 'Community citizenship'. ${ }^{28} \mathrm{EU}$ citizenship was created by the Treaties on European Union ${ }^{29}$ and bolstered in the European Union Charter of Fundamental Rights, ${ }^{30}$ and in Council Directive 2004/38/EC. ${ }^{31}$ From the very beginning, it was difficult to find consensus on what EU citizenship really meant. In the $1992 T E U$, article $8(1)$ stated that "[c]itizenship of the Union is hereby established. Every person

25 See J Shaw, The Transformation of Citizenship in the European Union (Cambridge University Press, 2007); Theodora Kostakopoulou, Citizenship, Identity and Immigration in the European Union (Manchester University Press, 2001); E Spaventa, 'Seeing the Wood Despite the Trees? On the Scope of Union Citizenship and its Constitutional Effects' (2008) 45(1) Common Market Law Review 13; A Cygan and E Szyszczak, 'Recent Developments in EU Citizenship and Fundamental Rights' (2006) 55 International and Comparative Law Quarterly 977.

26 See Christian Joppke, Citizenship and Immigration (Polity, 2010) 164.

27 See Dimitry Kochenov, 'The Essence of Eu Citizenship Emerging from the Last Ten Years of Academic Debate: Beyond the Cherry Blossoms and the Moon?' (2013) 62 International and Comparative Law Quarterly 97; U K Preuß, 'Problems of a Concept of European Citizenship' (1995) 1 European Law Journal 271; R Aron, 'Is Multinational Citizenship Possible?' (1974) 41 Social Research 638.

28 Revised Treaty of the Economic Community of West African States, opened for signature 24 July 1993, 2372 UNTS 233 (entered into force 23 August 1995) art 1: "Community citizen or citizens' means any national(s) of Member States who satisfy the conditions stipulated in the Protocol defining Community citizenship ..."); ECowAs, Protocol A $/ P .3 / 5 / 82$ relating to the definition of community citizen, EcowAs Doc A/P.3/5/82 (29 May 1982) art 1: "A citizen of the Community is: ....".

29 See Treaty on European Union, opened for signature 7 February 1992, [1992] OJ C 191/1 (entered into force 1 November 1993) art 8(1); Treaty of Amsterdam Amending the Treaty on European Union, the Treaties Establishing the European Communities and Certain Related Acts, opened for signature 2 October 1997, [1997] OJ C 340/1 (entered into force 1 May 1999) ('Treaty of Amsterdam') art 17(1); Treaty on the Functioning of the European Union (Consolidated version), opened for signature 25 March 1957, OJ C 326/47 (entered into force 1 January 1958) art 20.

30 See Charter of Fundamental Rights of the European Union, opened for signature 12 December 2007, OJ C 326 (1 December 2009).

31 See Directive 2004/38/EC of the European Parliament and of the Council of 29 April 2004 on the right of citizens of the Union and their family members to move and reside freely within the territory of the Member States [2004] OJ L 158/77. 
holding the nationality of a member State shall be a citizen of the Union". ${ }^{32}$ In 1997, the Treaty of Amsterdam, article 17, observed that "[c]itizenship of the Union shall complement and not replace national citizenship". ${ }^{33}$ Most recently, the 2012 TFEU restates the above as: "[e]very person holding the nationality of a Member State shall be a citizen of the Union. Citizenship of the Union shall be additional to and not replace national citizenship". ${ }^{34}$ The drafters of the EU treaties could easily have substituted the term 'participant' or 'beneficiary', or any number of alternatives to 'citizenship'. The provision in the EU treaties granting EU 'citizenship' also refers to member state 'nationality', using different terms in English, ${ }^{35}$ suggesting that different meanings were intended. Certainly, Eu citizenship was understood to be something additional to member state nationality, ${ }^{36}$ meaning it granted certain persons an additional status. In fact, it has been described as a form of "dual citizenship". ${ }^{37}$

Rather than only consulting the English text, we should also look at the other languages, after all the EU treaties are equally authentic in the other languages of the EU member states. ${ }^{38}$ Member state terminology on 'nationality'

32 See Treaty on European Union, art 8(1).

33 Treaty of Amsterdam, art 17(1).

34 Treaty on the Functioning of the European Union (Consolidated version), art 20.

35 See Treaty on the Functioning of the European Union (Consolidated version), art 20(1) (ex art $17 T E C$ ): "Citizenship of the Union is hereby established. Every person holding the nationality of a member state shall be a citizen of the Union").

36 See Treaty on the Functioning of the European Union (Consolidated version), art 20(1) (ex art $17 T E C$ ): "Citizenship of the Union shall be additional to and not replace national citizenship"; European Council Decision concerning certain problems raised by Denmark on the Treaty of European Union, Denmark and the Treaty on European Union, oJ C 3481 (31 December 1992), Annex 3, section A 'Citizenship'; Annette Schrauwen, 'European Union Citizenship in the Treaty of Lisbon: Any Change at All?' (2008) 15(1) Maastricht Journal of European and Comparative Law 55 .

37 See Secretariat of the European Convention, Treaty Establishing a Constitution for Europe, EU Doc CONV 369/02 (28 October 2002) art 5: "This article establishes and defines Union citizenship: every citizen of a Member State is a citizen of the Union; enjoys dual citizenship, national citizenship and European citizenship; and is free to use either, as he or she chooses; with the rights and duties attaching to each".

38 See Treaty on the Functioning of the European Union (Consolidated version), art 55(1) (ex art 53 TEU): "This Treaty, drawn up in a single original in the Bulgarian, Czech, Danish, Dutch, English, Estonian, Finnish, French, German, Greek, Hungarian, Irish, Italian, Latvian, Lithuanian, Maltese, Polish, Portuguese, Romanian, Slovak, Slovenian, Spanish and Swedish languages, the texts in each of these languages being equally authentic, shall be deposited in the archives of the Government of the Italian Republic, which will transmit a certified copy to each of the governments of the other signatory States". 
and 'citizenship' varies widely including in the way those terms were used in the various linguistic versions of the EU treaties. ${ }^{39}$ Some states make a distinction between citizenship and nationality, but only use the second term for ethnicity, not for the legal bond with the state ${ }^{40}$ Other states make the distinction only to differentiate the legal bond with the state (nationality) from the rights and duties of nationals (citizenship). ${ }^{41}$ Other states make no distinction at all, ${ }^{42}$ or at least do not make the distinction in their language versions of the EU treaties, ${ }^{43}$ which is perhaps very indicative that they intended the meaning of member state nationality and EU citizenship to be the same type of status. If a linguistic version makes a minor distinction between citizenship for EU purposes and member state nationality, the words used often rely on the same root word and concept. ${ }^{44}$ For its part, the European Commission

39 See Gerard-René de Groot, Towards a European Nationality Law (2004) (8)3 Electronic Journal of Comparative Law; Global Citizenship Observatory ('GLOBALCIT'), Citizenship $<$ http://globalcit.eu/glossary_citizenship_nationality/>.

40 See de Groot, above n 39; Global Citizenship Observatory ('GLOBALCiT'), Citizenship or Nationality? Austria <http://globalcit.eu/glossary_citizenship_nationality/>; Global Citizenship Observatory ('GLOBALCIT'), Citizenship or Nationality? Slovak Republic <http:// eudo-citizenship.eu/databases/citizenship-glossary/terminology> (observing that in the Slovak language a distinction is made between 'citizenship' (občianstvo) and 'nationality' (národnost'), with the latter being purely an ethnic term).

41 See Global Citizenship Observatory ('GLOBALCIT'), Citizenship <http://globalcit.eu/ glossary_citizenship_nationality/>: "Citizenship is generally used as a synonym for nationality ... Where citizenship is used in a meaning that is different from nationality it refers to the legal rights and duties of individuals attached to nationality under domestic law".

See Global Citizenship Observatory ('GLOBALCiт'), Citizenship: Malta <http://globalcit .eu/glossary_citizenship_nationality/> (observing that in the Maltese language only the term 'citizenship' is used; 'nationality' is not used); ibid at Finland (similarly observing that in the Finnish language only the term 'citizenship' (kansalaisuus) is used for both 'citizenship' and 'nationality'); ibid at Poland (similarly observing that in the Polish language only the term 'citizenship' (obywatelstwo) is used for both). But see ibid at Ireland (noting the unusual split but always used together term 'nationality and citizenship' (náisiúntacht agus saoránacht)); ibid at Spain (noting the unique usage of 'nationalities' of Spain (nacionalidades) in the Constitution).

43 See de Groot, above n 39, observing that both the Italian and Danish texts of the Maastricht Treaty used the same term for both 'citizenship' and 'nationality' (cittadinanza and borgerskab, respectively), but see Conclusions of the Presidency Edinburgh (12 December 1992) Annex 3, Unilateral Declaration of Denmark,.

44 See de Groot, above $\mathrm{n}$ 39, noting that the following versions of the Maastricht Treaty used the same root word for both 'nationality' and 'citizenship': Estonian (kdanik - kodakondsus), Hungarian (polgarsag - allampolgarsagot), Latvian (pilsonis - pilsoniba), Lithuanian 
acknowledges that the two terms are difficult to define and distinguish. ${ }^{45}$ Thus, only reading the text, there is no linguistic consensus that two different meanings for 'nationality' and 'citizenship' were intended in the Eu treaties, or if two meanings were intended, what the distinction was intended to be.

Beyond the inherent linguistic meanings, the question of the legal value of EU citizenship was discussed during initial negotiation and drafting, but it is still not entirely clear which meaning the member states intended as the final result. Only one state clearly argued that the two terms of 'nationality' and 'citizenship' did not bear the same meaning. Denmark entered a unilateral declaration at the Council Meeting in Edinburgh that "[n]othing in the Treaty on European Union implies or foresees an undertaking to create a citizenship of the Union in the sense of citizenship of a nation-state". ${ }^{46}$ This clarification is important because Denmark used the same term for both member state nationality and EU citizenship (borgerskab). Denmark continued by stating that "[c]itizenship of the Union is a political and legal concept which is entirely different from the concept of citizenship within the meaning of the Constitution of the Kingdom of Denmark and of the Danish legal system". ${ }^{47}$ Denmark's precise vision on EU citizenship is not completely clear from this communication. Denmark contrasted EU 'citizenship' with Danish 'citizenship' by arguing that EU citizenship was a "political and legal concept", but of course so is Danish citizenship, and that this "political and legal concept" was "entirely different" from citizenship under Danish law, but then it does not go on to explain what citizenship means under Danish law and how it is not a "political and legal concept". The better reading of the Danish submission is simply a confirmation that Danish nationality as a political and legal status was not being abolished and replaced. In any event, even if the declaration had any legal effects, those might be confined to only Denmark. The European Council reacted to this communication with the decision to simply affirm that $\mathrm{EU}$

(pilietybe - Sajungos pilietybie); Maltese (cittadinanza - cittadinanza ta'l-Unjoni), Polish (obywatelstwa - obywatelstwo), Slovak (statnemu obcianstvu - obcianstvo únie), and Swedish (medborgare i en medlemsstat - unionsmedborgare).

45 See Commission of the European Communities, Third Report from the Commission on Citizenship of the Union, EU Doc сом(2001)506 (7 September 2001).

46 See Conclusions of the Presidency Edinburgh (12 December 1992) Annex 3, Unilateral Declaration of Denmark,.

47 See European Council Decision concerning certain problems raised by Denmark on the Treaty of European Union, Denmark and the Treaty on European Union, oJ C 3481 (31 December 1992), Annex 3, [1]. 
citizenship does "not in any way take the place of national citizenship",48 but did not adopt the precise language of Denmark. This declaration was the ideal opportunity for the other member states to affirm that citizenship and nationality in the EU treaties were different concepts and yet the member states did not. Thus, the statement of this one state does not clarify the meaning in the EU treaty text and we might even go so far as to understand the remaining EU member states as rejecting the submission. Again, it is still at least arguable that 'citizenship' and 'nationality' were intended to mean the same legal status.

Denmark is correct, however, in that the EU is quite clearly not a state and the default understanding of 'nationality' is that it describes a legal bond with a state. ${ }^{49}$ As a supranational, international organization of a very unusual type, EU citizenship cannot be nationality in the sense that we ordinarily understand that term in international law. Of course, following that same line of reasoning, EU citizenship could also not be a citizenship either, because that status is also exclusively for a legal bond with a state. And in any event, it is unclear whether international law would really prohibit states from creating a nationality that was truly trans-national. Whether non-EU states would hesitate to consider EU citizenship a nationality does not exclude that the EU member states adopted a new understanding in their mutual relations. Setting aside arguments that the EU is effectively a state, ${ }^{50}$ the $\mathrm{EU}$ has at times enjoyed state-like features ${ }^{51}$ such as having "Union territory",52 conducting foreign

48 See ibid section A 'Citizenship'.

49 See G Close, 'Definitions of Citizenship' in J P Gardner (ed), Hallmarks of Citizenship: A Green Paper (British Institute of International and Comparative Law, 1994) 6; H U J d'Oliveira, Review of the Medullary Case (1993) 30 Common Market Law Review 632.

5o See Kramer et al (Joined Cases 3, 7, 6/76) [1976] ECR 1976-01279; E Stein, 'External Relations of the European Community' in (1990) 1(1) Collected Courses of the Academy of European Law 144; F Mancini, 'Europe: the Case for Statehood' (1998) 4 European Law Journal 29, 39-42. The Union does have exclusive competence to enter into international commitments to the exclusion of the member states where this authority flows even by implication from measures adopted by the committee institutions.

$5^{1} \quad$ See Teija Tiilikainen, 'To be or not to be? An Analysis of the Legal and Political Elements of Statehood in the EU's External Identity' (2001) 6(2) European Foreign Affairs Review 223, 228.

52 See Murat Dereci et al v Bundesministerium für Inneres (Case C-256/11) [2011] ECR 2011ooooo, [66]: "the territory of the Union as a whole". 
relations, ${ }^{53}$ rights of diplomatic or consular protection, ${ }^{54}$ or in generally applying a constitutional perspective to its founding treaties. ${ }^{55}$ In its relations with its citizens, the EU provides for voting both for European Parliament elections and local municipal elections. ${ }^{56}$ It would not be so exceptional to understand that one of the state-like aspects of the $\mathrm{EU}$ is to form a state-like legal bond directly with individuals, substantively comparable to nationality.

The various organs of the Eu have affirmed this view and pursued a policy of treating $\mathrm{E}$ citizenship as a distinct status, in fact as "the fundamental status". ${ }^{57}$

53 See Treaty on European Union, opened for signature 7 February 1992, [1992] OJ C 191/1 (entered into force 1 November 1993) arts 14(1), (3), 16(3), 17(2); Ivor Roberts (ed), Satow's Diplomatic Practice 399 (Oxford University Press, 6th ed, 2009); Ben Rosamond, 'Conceptualizing the EU Model of Governance in World Politics' (2005) 10(4) European Foreign Affairs Review 463, 465.

54 See Treaty on the Functioning of the European Union (Consolidated version), opened for signature 25 March 1957, OJ C 326/47 (entered into force 1 January 1958) art 20(2)(c) (ex art $17 T E C$ ): "Citizens of the Union shall enjoy ... the right to enjoy, in the territory of a third country in which the Member State of which they are nationals is not represented, the protection of the diplomatic and consular authorities of any Member State on the same conditions as the nationals of that State"); art 23 (ex art 20 TEC); Charter of Fundamental Rights of the European Union, opened for signature 12 December 2007, oJ C 326 (1 December 2009) art 46.

55 See $N V$ Algemene Transport- en Expeditie Onderneming van Gend \& Loos $v$ Netherlands Inland Revenue Administration (C-26-62) [1963] ECR 1: the EU is "a new legal order of international law for the benefit of which the States have limited their sovereign rights".

56 See Treaty on the Functioning of the European Union (Consolidated version), opened for signature 25 March 1957, OJ C 326/47 (entered into force 1 January 1958) art 2o(2)(b) (ex art 17 $T E C$ ): "Citizens of the Union shall enjoy the ... the right to vote and to stand as candidates in elections to the European Parliament and in municipal elections in their Member State of residence, under the same conditions as nationals of that State"; art 22; Charter of Fundamental Rights of the European Union, opened for signature 12 December 2007, OJ C 326 (1 December 2009) art 12.

57 See Marín v Admin del Estado (European Court of Justice, C-165/14, 13 September 2016) (Opinion of the Advocate General Szpunar) [107]-[110] and Secretary of State for the Home Department v cs (European Court of Justice, C-304-14, 13 September 2016); Martens v Minister van Onderwijs, Cultuur en Wetenschap (European Court of Justice, C-359/13, 26 February 2015) [21]; Laurence Prinz v Region Hannover and Philipp Seeberger v Studentenwerk Heidelberg (European Court of Justice, C-523/11 and C-585/11, 18 July 2013) [24]; Murat Dereci et al v Bundesministerium für Inneres (Case C-256/11) [2011] ECR 2011-00ooo; Rottman v Freistaat Bayern (C-135/08) [2010] ECR I-01449, [43]; Heinz Huberv Bundesrepublik Deutschland (C-524/06) OJ C 44, [69]; Commission of the European Communities v Kingdom of the Netherlands (European Court of Justice, C-50/o6, 7 June 2007) [32]; Kingdom of Spain v United Kingdom of Great Britain and Northern Ireland (C-145/04) [2006] 
Directive 2004/38/EC on the right of citizens of the Union and their family members to move and reside freely within the territory of the member states observes that "Union citizenship should be the fundamental status of nationals of the Member States when they exercise their right of free movement and residence". 58 The Court of Justice has also held that EU citizenship was not merely the bundle of economic rights granted under the Treaties on European Union, ${ }^{59}$ but a status, ${ }^{60}$ expressive of a social role in the Union. ${ }^{61}$ This is language perhaps deliberately reminding us of Nottebohm's "genuine link" criterion. ${ }^{62}$ The Court has also used similar language as Directive 2004/38/EC when it concluded that EU citizenship "is destined to be the fundamental status of nationals of the Member States". ${ }^{63}$ Thus, EU citizenship is a distinct

ECR I-07917, [74]; Bidar v London Borough of Ealing and Secretary of State for Education and Skills (C-209/03) [2005] ECR I-02119, [31]; Commission of the European Communities v Republic of Austria (C-147/03) [2005] ECR I-05969, [45]; Schempp v Finanzamt München $V(\mathrm{C}-403 / 03)$ [2005] ECR I-06421, [15]; Pusa v Osuuspankkien Keskinäinen Vakuutusyhtiö (C-224/02) [2004] ECR I-05763, [16]; Zhu and Chen $v$ Secretary of State for the Home Department (C-200/02) [2004] ECR I-09925, [25]; Avello v Belgian State (C-148/02) [2003] ECR I-11613, [22]; Orfanopoulos and Ors and Oliveriv Land Baden-Württemberg (C-482/01, C-493/01) [2004] ECR I-05257, [65]; Baumbast and $R v$ Secretary of State for the Home Department (C-413/99) [2002] ECR I-07091, [82]; D'Hoop v Office national de l'emploi (C-224/98) [2002] ECR I-06191, [28]; Grzelczyk v Centre public d'aide sociale d'OttigniesLouvain-la-Neuve (C-184/99) [2001] ECR I-06193, [31]-[33]; Criminal proceedings against Horst Otto Bickel and Ulrich Franz (C-274/96) [1998] ECR I-07637, [15]-[16].

$5^{8}$ See Directive 2004/38/EC of the European Parliament and of the Council of 29 April 2004 on the right of citizens of the Union and their family members to move and reside freely within the territory of the Member States [2004] oJ L 158/77, preamble [3]; Avellov Belgian State (C-148/02) [2003] ECR I-11613; D'Hoop v Office national de l'emploi (C-224/98) [2002] ECR I-06191; Bidar $v$ London Borough of Ealing and Secretary of State for Education and Skills (C-209/03) [2005] ECR I-02119; Schempp v Finanzamt München v (C-403/03) [2005] ECR I-06421; Tas-Hagen and Tas $v$ Raadskamer wUво van de Pensioen- en Uitkeringsraad (C-192/05) [2006] ECR I-10451; S O'Leary, The Evolving Concept of Community Citizenship: From the Free Movement of Persons to Union Citizenship (Kluwer Law, 1996).

59 See D'Hoop v Office national de l'emploi (C-224/98) [2002] ECR I-06191.

6o See Martínez Sala v Freistaat Bayern (C-85/96) [1998] ECR I-02691; Levin v Staatssecretaris van Justitie (53/81) [1982] ECR 01035.

61 See Kempf $v$ Staatssecretaris van Justitie (139/85) [1986] ECR 01741; Luisi and Carbone $v$ Ministero del Tesoro (286/82, 286/83) [1984] ECR 00377; Levin v Staatssecretaris van Justitie (53/81) [1982] ECR 01035; P Craig and G de Búrca, EU Law: Text, Cases and Materials (Oxford University Press, 3rd ed, 2003) 706-711.

$62 \quad$ Nottebohm Case (Liechtenstein v Guatemala) (Judgment, Second Phase) [1955] ICJ Rep 4, 8.

63 See Marín v Admin del Estado (European Court of Justice, C-165/14, 13 September 2016) (Opinion of the Advocate General Szpunar) [107]-[110] and Secretary of State for the Home 
social and legal status putting the individual in a direct legal relationship with the $\mathrm{EU},{ }^{64}$ an independent legal order. ${ }^{65}$

Department v cs (European Court of Justice, C-304-14, 13 September 2016); Martens v Minister van Onderwijs, Cultuur en Wetenschap (European Court of Justice, C-359/13, 26 February 2015) [21]; Laurence Prinz v Region Hannover and Philipp Seeberger v Studentenwerk Heidelberg (European Court of Justice, C-523/11 and C-585/11, 18 July 2013) [24]; Murat Dereci et al v Bundesministerium für Inneres (Case C-256/11) [2011] ECR 2011-00000; Rottman v Freistaat Bayern (C-135/08) [2010] ECR I-01449, [43]; Heinz Huberv Bundesrepublik Deutschland (C-524/06) oJ C 44, [69]; Commission of the European Communities $v$ Kingdom of the Netherlands (European Court of Justice, C-50/o6, 7 June 2007) [32]; Kingdom of Spain $v$ United Kingdom of Great Britain and Northern Ireland (C-145/04) [2006] ECR I07917, [74]; Bidarv London Borough of Ealing and Secretary of State for Education and Skills (C-209/03) [2005] ECR I-02119, [31]; Commission of the European Communities $v$ Republic of Austria (C-147/03) [2005] ECR I-05969, [45]; Schempp v Finanzamt München V(C-403/03) [2005] ECR I-06421, [15]; Pusa v Osuuspankkien Keskinäinen Vakuutusyhtiö (C-224/o2) [2004] ECR I-05763, [16]; Zhu and Chen $v$ Secretary of State for the Home Department (C200/02) [2004] ECR I-09925, [25]; Avello v Belgian State (C-148/02) [2003] ECR I-11613, [22]; Orfanopoulos and Ors and Oliveri v Land Baden-Württemberg (C-482/01, C-493/o1) [2004] ECR I-05257, [65]; Baumbast and R $v$ Secretary of State for the Home Department (C-413/99) [2002] ECR I-07091, [82]; D'Hoop v Office national de l'emploi (C-224/98) [2002] ECR I-06191, [28]; Grzelczyk v Centre public d'aide sociale d'Ottignies-Louvain-la-Neuve (C184/99) [2001] ECR I-06193, [31]-[33]; Criminal proceedings against Horst Otto Bickel and Ulrich Franz (C-274/96) [1998] ECR I-07637, [15]-[16].

64 See Ruiz Zambranov Office national de l'emploi (C-34/o9) [2011] ECR I-01177; Konstantinidis $v$ Stadt Altensteig (C-168/91) [1993] ECR I-01191 (Opinion of the Advocate General Jacobs) [46]: "a Community national ... is in addition entitled to assume that, wherever he goes to earn his living in the European Community, he will be treated in accordance with a common code of fundamental values, in particular those laid down in the European Convention on Human Rights. In other words, he is entitled to say 'civis europeus sum' and to invoke that status in order to oppose any violation of his fundamental rights"; M Shaw, 'Political Rights and Multilevel Citizenship in Europe' in E Guild, K Groenendijk, and S Carrera (eds), Illiberal Liberal States: Immigration, Citizenship and Integration in the $E U$ (Ashgate, 2009) 29; Dimitry Kochenov, 'The Essence of Eu Citizenship Emerging from the Last Ten Years of Academic Debate: Beyond the Cherry Blossoms and the Moon?' (2013) 62 International and Comparative Law Quarterly 97; Henri de Waele, 'Eu Citizenship: Revisiting its Meaning, Place and Potential' (2010) 12 European Journal of Migration and Law 319; C Schönberger, 'European Citizenship as Federal Citizenship: Some Citizenship Lessons of Comparative Federalism' (2007) 19 Review of European Public Law 61.

65 See Rottman v Freistaat Bayern (C-135/08) [2010] ECR I-01449 (Opinion of the Advocate General Maduro) [23]; Kreilv Bundesrepublik Deutschland (C-285/98) [2000] ECR I-00069; R Wessel, 'The Dynamics of the European Union Legal Order: An Increasingly Coherent Framework of Action and Interpretation' [2009] 5 European Constitutional Law Review 117. 
EU citizenship is, however, partly dependent on member state nationality, but only for purposes of acquisition of the status. EU citizenship is acquired when a person has EU member state nationality. ${ }^{66}$ Member states have a considerable say over who acquires EU citizenship. Whether a person holds EU member state nationality is to be determined primarily by the nationality laws of the member state. ${ }^{67}$ Member states have a wide degree of discretion in

66 See Treaty on the Functioning of the European Union (Consolidated version), opened for signature 25 March 1957, OJ C 326/47 (entered into force 1 January 1958) art 20(1) (ex art 17 TEC); Marín v Admin del Estado (European Court of Justice, C-165/14, 13 September 2016) (Opinion of the Advocate General Szpunar) [107] and Secretary of State for the Home Department v cs (European Court of Justice, C-304-14, 13 September 2016); Ruiz Zambrano $v$ Office national de l'emploi (C-34/o9) [2011] ECR I-01177, [40]; Baumbast and Rv Secretary of State for the Home Department (C-413/99) [2002] ECR I-07091, [82]-[84]; D'Hoop v Office national de l'emploi (C-224/98) [2002] ECR I-06191, [27]; Directive 2004/38/EC of the European Parliament and of the Council of 29 April 2004 on the right of citizens of the Union and their family members to move and reside freely within the territory of the Member States [2004] OJ L 158/77, art 2(1); Commission of the European Communities, Fourth Report on Citizenship of the Union, EU Doc сом(2004)695 (26 October 2004); Commission of the European Communities, Report on the Citizenship of the Union, EU Doc COM(93)702 (21 December 1993).

67 See European Council Decision concerning certain problems raised by Denmark on the Treaty of European Union, Denmark and the Treaty on European Union, of C 3481 (31 December 1992), Annex 3, section A 'Citizenship'; Micheletti and Ors v Delegación del Gobierno en Cantabria (C-369/90) [1992] ECR I-04239; Commission of the European Communities, Report on the Citizenship of the Union, EU Doc сом(93)702 (21 December 1993): "wherever in the Treaty establishing the European Community reference is made to nationals of the Member States, the question whether an individual possesses the nationality of a Member State shall be settled solely by reference to the national law of the Member State concerned"; Commission of the European Communities, Third Report from the Commission on Citizenship of the Union, EU Doc Сом(2001)506 (7 September 2001): "It is therefore worth pointing out that: - it is for each Member State to lay down the conditions for acquiring and losing the nationality of that state"; Commission of the European Communities, Fourth Report on Citizenship of the Union, EU Doc сом(2004)695 (26 October 2004): "Without prejudice to the fact that the Member States alone remain competent in the area of nationality laws, the Commission has presented its views on naturalisation of legal migrants in the Communication on immigration, employment and integration in 2003"; Commission of the European Communities, Fifth Report on Citizenship of the Union, EU Doc сом(2008)85 (15 February 2008); Note to the Government of the Italian Republic Concerning a Declaration Replacing the Declaration on the Definition of the Term 'National' Made at the Time of Signature of the Treaty of Accession of 22 January 1972, signed 31 December 1982, UKTs 67 (1983). 
prescribing their nationality laws. ${ }^{68}$ Member states also have a degree of control over which of their nationals acquire EU citizenship, by declaring which persons are 'nationals' under their nationality law for purposes of EU citizenship, such as nationals connected to overseas territories. ${ }^{69}$ While acquisition of EU citizenship does depend on member state nationality, ${ }^{70} \mathrm{EU}$ citizenship is largely independent of member state nationality otherwise. ${ }^{71}$ Thus there is an 'independent' EU citizenship that is nonetheless 'linked' to EU member state nationality in terms of acquisition. ${ }^{72}$ However, this unusual, derivative method of acquiring status does not necessarily mean that the status itself is inherently derivative or dependent, or of some other second order.

For the argument in this paper, we do not need to conclude that EU citizenship is a true nationality with the entire social and legal meaning of that term; instead we only need to conclude that EU citizenship is a direct legal bond between an individual and the Union. After all, it is that legal bond that

68 See Rottman v Freistaat Bayern (C-135/08) [2010] ECR I-01449, [49]; The Queen $v$ Secretary of State for the Home Department, ex parte: Manjit Kaur (C-192/99) [2001] ECR I-01237.

69 See Note to the Government of the Italian Republic Concerning a Declaration Replacing the Declaration on the Definition of the Term 'National' Made at the Time of Signature of the Treaty of Accession of 22 January 1972, signed 31 December 1982, UKTS 67 (1983): “(a) British citizens; (b) Persons who are British subjects by virtue of Part IV of the British Nationality Act 1981 ....". Also note that the UK excluded certain EU citizenship rights from UK nationals in Jersey, Guernsey and Man who are EU citizens, but do not have the right to free movement. This was only possible because the exclusion was included in the EU treaties and those persons never acquired the rights in the first place. It would be quite a different matter for the UK to attempt to revoke those rights. Treaty on the Functioning of the European Union (Consolidated version), opened for signature 25 March 1957, oJ C 326/47 (entered into force 1 January 1958) art 355(5)(c) (ex art 299(2), 1st sub-paragraph and art 299(3)-(6) TEC): "the Treaties shall apply to the Channel Islands and the Isle of Man only to the extent necessary to ensure the implementation of ... the European Economic Community and ... European Atomic Energy Community". See also Treaty amending, with regard to Greenland, the Treaties establishing the European Communities, signed 13 March 1984, [1985] oJ L 29 (entered into force 1 February 1985) Protocol No 4 on Greenland.

70 See Rottman v Freistaat Bayern (C-135/08) [2010] ECR I-01449, [48]; Marín v Admin del Estado (European Court of Justice, C-165/14, 13 September 2016) (Opinion of the Advocate General Szpunar) [108] and Secretary of State for the Home Department $v$ cs (European Court of Justice, C-304-14, 13 September 2016).

71 See D Kochenov, 'Ius Tractum of Many Faces: European Citizenship and the Difficult Relationship between Status and Rights' (2009) ${ }_{15}$ Columbia Journal of European Law 181.

72 See Rottman v Freistaat Bayern (C-135/08) [2010] ECR I-01449, [48]; Marín v Admin del Estado (European Court of Justice, C-165/14, 13 September 2016) (Opinion of the Advocate General Szpunar) [108] and Secretary of State for the Home Department $v$ cs (European Court of Justice, C-304-14, 13 September 2016). 
international law protects from revocation. Whatever EU citizenship is, there is no doubt that it is a direct legal bond between the individual and the Union that is functionally comparable to nationality. This understanding is implied in suggestions that EU citizenship is a form of 'dual citizenship'. Thus, EU citizenship is minimally sufficient to benefit from the protections of international law.

Before examining Brexit specifically, we can first wonder what rules govern loss of EU citizenship distinct from the rules governing loss of member state nationality. An initially attractive interpretation is to apply the law of treaties and assume that when a state is no longer a party to the treaty, then individuals lose their EU citizenship. But this interpretation views EU citizenship as merely a treaty benefit for individuals, not as a fundamental status bringing the individual into a direct, constitutional legal relationship with the Union. Having served its function as gatekeeper to acquisition of status, the member state ceases to serve as an intermediary for the status of the person. If a state withdraws from the Union, the Union still continues and still has the capability to maintain a legal bond with individuals. The question here is whether the withdrawing state, as a part of its withdrawal, has the ability to break the fundamental legal bond the individual has with the Union, and whether that break would comply with human rights.

Unlike the terms on acquisition of EU citizenship, EU law has no terms on loss of EU citizenship. This suggests, for example, that EU citizenship might not be separately renounced, among other considerations. Many authorities have concluded that because EU citizenship is linked to member state nationality for acquisition, that a person both acquires and retains EU citizenship only for so long as he or she retains EU member state nationality, ${ }^{73}$ or the state

73 See Treaty on the Functioning of the European Union (Consolidated version), opened for signature 25 March 1957, oJ C 326/47 (entered into force 1 January 1958) art 20 (ex art 17 TEC); Commission of the European Communities, Third Report from the Commission on Citizenship of the Union, EU Doc сом(2001)506 (7 September 2001): "Citizenship of the Union, as commentators have pointed out, is thus something 'superimposed' on national and in some cases regional or local citizenship to give the effect of multiple levels"; Marin $v$ Admin del Estado (European Court of Justice, C-165/14, 13 September 2016) (Opinion of the Advocate General Szpunar) [107] and Secretary of State for the Home Department v cs (European Court of Justice, C-304-14, 13 September 2016); Kay Hailbronner, 'Nationality in Public International Law and European Law' in Rainer Bauböck (ed), Acquisition and 
retains EU membership. But this requirement is not explicitly indicated in the EU treaties. Failure to include terms on loss in the EU treaties might just mean that loss is governed by the default rules on loss of this kind of legal bond in international law. Even if we were to disagree and understand that an individual must continue to retain member state nationality, and that the state must continue to hold EU membership, in order to retain EU citizenship, we would still need to comply with international human rights law that governs loss of nationality more vigorously than acquisition of nationality. At a minimum, surely a silence in the treaty should be interpreted in compliance with international human rights. Thus, a better interpretation of the retention of EU citizenship, consistent with human rights, is to understand the acquisition of EU citizenship as dependent on member state nationality, but the loss of EU citizenship would be treated somewhat differently. Whether or not EU citizenship was lost would be constrained by the prohibition against arbitrary revocation, and the conclusion on EU citizenship could be different from that on member state nationality.

The jurisprudence of the CJEU to date suggests that the loss of EU citizenship is subject to these considerations. The CJEU has held in Kaur and Rottman that the acquisition and loss of nationality present significantly different situations. ${ }^{74}$ For example, whether or not an individual has a real connection to the member state (and Union) in the sense of Nottebohm ${ }^{75}$ is only assessed at the moment of acquisition. ${ }^{76}$ It is not constantly monitored and revoked; nationality is maintained so long as it was correctly acquired. Prior to a grant of nationality, the individual has no EU rights. ${ }^{77}$ It is only after acquisition of EU

Loss of Nationality: Policies and Trends in 15 European Countries (Amsterdam University Press, 2006) 37 .

74 See The Queen $v$ Secretary of State for the Home Department, ex parte: Manjit Kaur (C-192/99) [2001] ECR I-01237; Rottman v Freistaat Bayern (C-135/08) [2010] ECR I-01449, [49]; Micheletti and Ors v Delegación del Gobierno en Cantabria (C-369/9o) [1992] ECR I04239, [10]; Pham v Secretary of State for the Home Department [2015] UKSC 19, [45] (per Lord Carnwath).

75 Nottebohm Case, above n 10.

76 See International Law Commission, 'Draft Articles on Nationality of Natural Persons in relation to the Succession of States, with commentaries' [1999] 11(2) Yearbook of the International Law Commission, art 5; D P O'Connell, State Succession in Municipal Law and International Law (Cambridge University Press, 1967) 518; I Brownlie, 'The relations of nationality in public international law' (1963) 39 British Yearbook of International Law 318.

77 See The Queen $v$ Secretary of State for the Home Department, ex parte: Manjit Kaur (C-192/99) [2001] ECR I-01237. 
citizenship that he or she acquires those rights. ${ }^{78}$ For example, the applicant in Kaur was unsuccessful in arguing that she had been deprived of EU citizenship by the UK because, according to the CJEU, she had never acquired citizenship in the first place and never acquired the protection from deprivation. Thus, EU law recognises that protection of nationality from loss is more rigorous than protection of the acquisition of nationality. Partly on this basis, the Court of Justice has concluded that when revoking nationality, the member state impacts the individual's EU citizenship, thus EU law may limit the state's freedom of action. This finding was based on understanding EU citizenship as its own distinct status, creating a link between the $\mathrm{EU}$ citizen and the $\mathrm{EU}$, and not necessarily mediated by the member state. ${ }^{79}$

In addition, practice on the severability of $\mathrm{E} U$ citizenship and member state nationality is also supportive of the conclusions in this paper. In the case of Greenland, practice has confirmed that individuals retain EU citizenship even when their territory exits the Union. ${ }^{80}$ Greenland was initially included in the EU, so when Denmark joined the EU, Danish (Greenlander) nationals became EU citizens. In a curious twist, Greenland later requested that it be excluded from the $\mathrm{EU}$, which was accomplished by treaty. ${ }^{81}$ Its nationals are still considered to be EU citizens, even though the territory of Greenland is no longer part of the Union. ${ }^{82}$ Since this case was about loss of acquired citizenship, states and the EU have far less ability to restrict citizenship. This conclusion is reinforced by the entirely different treatment of people from the Faroe Islands. Inhabitants of the Faroe Islands hold Danish nationality but from the founding of the EU, the Faroe Islands were excluded from the Union in the Danish accession treaty, ${ }^{83}$ so the Faroese, even though holding member state nationality,

78 See Rottman v Freistaat Bayern (C-135/08) [2010] ECR I-01449, [48].

79 See ibid [49].

80 When Algeria seceded from France in 1962 it left the European Community, as it was known at the time. This process occurred before the creation of the European Union and before the creation of EU Citizenship. See Cabinet Office, The Process for Withdrawing from the European Union (Government of the United Kingdom, 2016) fn 3 (available at <https://www.gov .uk/government/publications/the-process-for-withdrawing-from-the-european-union>).

81 See Treaty amending, with regard to Greenland, the Treaties establishing the European Communities, signed 13 March 1984, [1985] OJ L 29 (entered into force 1 February 1985) Protocol No 4 on Greenland.

82 See Gerard-René De Groot, 'Zum Verhältnis der Unionsbürgerschaft zu den Staatsangehörigkeiten in der Europäischen Union' in Peter Christian Müller-Graf (ed), Europäisches Integrationsrecht im Querschnitt (Nomos 2003) 73.

83 See Treaty on the Functioning of the European Union (Consolidated version), opened for signature 25 March 1957, oJ C 326/47 (entered into force 1 January 1958) art 355(5)(a) 
never acquired EU citizenship. This outcome is acceptable because the people of the Faroe Islands were excluded from EU citizenship, and member states have far more discretion in matters of citizenship acquisition than loss. Thus, EU practice in these cases show that acquisition and loss are not simple opposites, but have significantly different considerations, and that the loss of EU citizenship can be avoided when a territory leaves the Union.

It could be argued that it cannot be the intention of EU citizenship that millions of people living outside of the Union have a right to reside in the Union, without some sort of territorial reciprocity. In order to sustain this argument, the Greenland example would have to be set aside as a non-significant number of people with a negligible impact on the total numbers of EU citizens. Of course, this argument could not be legally sustained because there are no terms anyway conditioning EU citizenship on the status of the territory in which the person lives. In fact, many persons who live in territories outside the EU qualify for EU citizenship due to political union with a European state, such as the Caribbean territories within the Dutch Kingdom. Additionally, millions of people living outside the Union hold Eu citizenship, for example, due to dual nationality in Spain or Italy, and a South American state. ${ }^{84}$ At the time of the creation of EU citizenship, people in this status were well known and could easily have been excluded, but they were not. Sheer numbers of overseas EU citizens could not be a way to interpret the terms of EU citizenship.

Returning to the specific case of Brexit, the question is whether British citizens that acquired EU citizenship will lose it now under a Brexit scenario. EU citizenship is not being abolished, nor are UK nationals losing their UK nationality and consequently EU citizenship. Rather, it is being proposed that some EU citizens, those who acquired their EU citizenship via the UK, will lose their EU citizenship, and therefore their legal bond with the Union. Thus, we are discussing a situation of loss of EU citizenship only and we do not have a Rottman situation. Certainly, any person acquiring British citizenship after Brexit will not be acquiring an EU member state nationality and consequentially will not be acquiring EU citizenship. However, what is the outcome for British citizens that have already acquired EU citizenship?

As detailed above, contemporary international law limits a state's ability to abolish the fundamental legal bond, usually expressed as nationality, against

(ex art 299(2), 1st sub-paragraph and art 299(3)-(6) TEC): "the Treaties shall not apply to the Faeroe Islands".

84 In this regard, see Micheletti and Ors $v$ Delegación del Gobierno en Cantabria (C-369/9o) [1992] ECR I-04239 (holding that the EU citizenship of a dual EU/non-EU national could not be refused). 
the will of the person. Revocation must serve a legitimate purpose, ${ }^{85}$ not be arbitrary (or discriminatory), ${ }^{86}$ and be proportionate. ${ }^{87}$ These rules certainly bind the UK, but perhaps also the $\mathrm{EU}$ as an international legal person that has pledged to adhere to fundamental human rights. Nationality revocation would instead need to be individualised and potentially only imposed at the will of the person concerned. ${ }^{88}$ If the terms of the UK-EU Brexit agreement permitted UK nationals to renounce their EU citizenship, and did not deprive them of it against their will, this provision would be acceptable. In addition, insofar as Brexit might have an analogy with state succession or secession, it would be critical that individuals have a right of option so that they do not have nationality removed or imposed against their will. For example, and not without a bit of irony, EU citizenship might be revoked only from those persons who voted in favor of Brexit.

The rules on revocation of nationality/citizenship say that states may not revoke nationality where it is arbitrary or discriminatory. Where the terms on revoking EU citizenship are explicit or reasonably implied, we can conclude that the rule is not arbitrary in the sense of operating without law. Of course, this conclusion is dependent on the UK's compliance with its own constitution, and of course, as an international law standard, the UK's views on this matter would not be determinative. ${ }^{89}$

However, arbitrariness has a substantive aspect as well. Several substantive issues can be identified. For example, looking at UK nationals resident or with long standing ties to EU member states, these individuals may have investments, homes, and lives that are rendered unstable and unpredictable. As mentioned above, revocation of the protected legal bond would need to be proportionate under international law, yet loss of EU citizenship is not necessary in order for the UK to leave the Union, as the practice of Greenland has shown. Perhaps an argument could be made that loss of EU citizenship is necessary to manage the large numbers of persons in the UK who would hold the right to live in the EU? We have already addressed the argument of large numbers of persons with rights in the $\mathrm{EU}$ by reference to the millions of dual nationals and

\footnotetext{
85 Rottman v Freistaat Bayern (C-135/08) [2010] ECR I-01449, [51].

86 See ibid [53].

87 See ibid [55].

88 See European Convention on Nationality, opened for signature 6 November 1997, ETS 166 (entered into force 1 March 200o) arts 7(3) (limitations on loss of nationality) and 5(1) (providing for grounds which are per se procedurally or substantively arbitrary).

89 See Ivcher Bronstein v Peru (Inter-American Court of Human Rights, Case No 11.762, 3 March 1998).
} 
others already enjoying such rights. In addition, this article is agreeing that any person acquiring UK nationality after Brexit would not acquire EU citizenship, so the class of persons with UK nationality and retaining EU citizenship would be a slowly diminishing, and eventually extinguishing, class anyway. Given the drastic consequences of loss of EU citizenship on many individuals, for example, loss of residency rights in an EU member state where a UK national has resided for a significant period of time, the revocation of EU citizenship in this manner would not be proportionate to the goal of the UK leaving the EU. Even if the remaining EU member states granted rights to UK nationals that were equivalent to those previously enjoyed as EU citizens, this action could not replace the fundamental legal bond these individuals have with the Union. International law protects the legal bond, not just a bundle of rights. It is the destruction of that bond that needs to be proportionate. Permitting British nationals to retain their EU citizenship and its rights would not be out of step with other existing EU policy. None of the precedents, from Greenland to dual nationals, shows that loss of EU citizenship has ever been seen in the past as necessary to limit persons coming to the $\mathrm{EU}$ from non-EU territories or to achieve the goal of a territory leaving the Union.

5

Conclusion

This article takes EU citizenship seriously as a protected legal bond, functionally equivalent to citizenship. Until now, discussions on EU citizenship and Brexit have applied a law of treaties framework, or perspective informed by the law of international organizations. What has been lost in the discussion is the viewpoint from human rights.

It is important to know what this article does not conclude. It does not conclude that anyone acquiring UK nationality after Brexit can acquire EU citizenship. That is clearly excluded. Nor does this article seek to reverse Brexit. That is also clearly the state's sovereign prerogative, providing article $5^{\circ}$ of the $T E U$ is followed. It only concludes that, at a minimum, any person currently holding or acquiring British citizenship up to and until the UK ceases to be a member state of EU, also acquires EU citizenship and cannot have it arbitrarily revoked upon Brexit. EU citizenship constitutes a distinct legal bond between the individual and the Union, and international law imposes restrictions on revoking such legal bonds arbitrarily. As revocation of EU citizenship is not necessary for the UK to leave the EU, it is difficult to justify as non-arbitrary, especially given its consequences. 
Of course, it might be complicated from a logistical perspective for a UK national with EU citizenship to continue enjoying it. How would the UK national that retained EU citizenship be distinguished from the UK national that does not? UK passports will revert to the old blue design, missing the 'European Union' inscription. In fact, arguably the UK would be prohibited from placing 'European Union' on any UK passport, even when the bearer retained EU citizenship. This difficulty is a problem, but it is not a problem of legal status, instead it is a problem of evidence of status. Any complex situations are a result of the failure of EU regulation to account for the legal consequences of EU citizenship, are not an argument for violating human rights. Perhaps it is time for the $\mathrm{EU}$ to provide for a clear, predictable mechanism for terminating EU citizenship, consistent with human rights. This mechanism could take the form of an EU citizenship renunciation process. It might also argue in favour of the EU issuing a distinct form of citizenship identification separate from national passports.

On a final note, perhaps Brexit might be forcing a rapid maturity of EU citizenship. EU citizenship has so far been evolving slowly, both in terms of discovering its original intent and exploring the outer bounds of the meaning of the legal bond. Without Brexit, this evolution might have continued largely undisturbed, perhaps moving even more slowly. However, the shock of the UK referendum contrasted with the assumed stability of the Union legal order, and now the threat of uprooting millions of UK-EU citizens, demands that we take a hard look at the present nature of EU citizenship and acknowledge that it has emerged as a civil status in its own right directly under Union law. This status cannot be so easily terminated without doing violence to the human rights of those enjoying EU citizenship. 